\title{
PENANGANAN GAS ASAM ( SOUR GAS ) YANG TERKANDUNG DALAM GAS ALAM MENJADI SWEETENING GAS
}

\author{
Muhrinsyah Fatimura ${ }^{(1)}$, Reno Fitriyanti ${ }^{(2)}$,Rully Masriatini ${ }^{(3)}$ \\ ${ }^{(1,2,3)}$ Dosen Universitas PGRI Palembang \\ Fakultas Teknik Program Studi Teknik Kimia \\ email:muhrinsyah.f@gmail.com
}

\begin{abstract}
ABSTRAK
Gas alam merupakan sumber energi dan bahan baku yang terdapat dialam baik itu terdapat sebagai Associated gas maupun non Associated gas. Keberadaannya dialam membuat gas alam tidak dalam keadaan murni, kandungan gas alam dari beberapa sumber berbeda-beda komposisinya tergantung dari sumber dan lokasi pengeksplorasian demikian juga impurities yang terkandung didalamnya. Gas asam (sour gas ) merupakan salah satu kandungan impurities yang terdapat dalam gas alam seperti $\mathrm{CO}_{2}, \mathrm{H}_{2} \mathrm{~S}$, mercaptan. Keterikutan sour gas kedalam gas alam dalam proses selanjutnya dapat menyebabkan korosif pada peralatan, mengurangi heating value pada gas alam, racun pada katalis serta pada proses pencairan gas alam dapat menjadi icing atau padat sehingga dapat menghambat transportasi gas alam. Kandungan sour gas dalam gas alam yang pernah di analisa berkisar antara range terendah $>10 \%$ dan tertinggi $>60 \%$ sehingga memerlukan penangan khusus untuk menghilangkannya .Untuk range $>10 \%$ proses yang digunakan yaitu dengan cara Absorpsi Kimia, Absorpsi Fisik, Absorpsi Fisik-Kimia, Adsorpsi Fisik dengan menggunakan berbagai absorben Mononethanolamine (MEA), Diglycolamine (DGA), Diethanolamine (DEA), Diisopropanolamine (DIPA), Methyldiethanolamine (MDEA), alternative absorben Potasium Karbonat $\left(\mathrm{K}_{2} \mathrm{CO}_{3}\right)$. Untuk Sour gas yang kandungan tinggi $>60 \%$ penanganan Fraksinasi/Cryogenic dan Permeation (membran). Sehingga sour gas bisa-terbebas dari impurities yang mengikutinya menjadi Sweetening Gas.
\end{abstract}

Kata Kunci: Gas Alam, Sour gas , Sweetening Gas, , Absorben

\section{PENDAHULUAN}

Salah satu sumber energi yang terdapat di alam adalah gas alam pemanfaatannya banyak digunakan baik selain sebagai sumber energi atau sebagai bahan baku dalam pembuatan suatu proses produksi kimia misalnya sebagai bahan bakar boiler di furnace,Reformer. Gas alam juga digunakan sebagai bahan baku produksi amoniak, metanol dan lain-lain.Gas alam memiliki komponen utama yaitu metana $\left(\mathrm{CH}_{4}\right)$ disamping juga ada hidrokarbon ringan lainya yang terbentuk secara alami. Didalamnya tercampur juga beberapa senyawa non-hidrokarbon.

Karakter dari Gas alam murni yaitu tidak berwarna, tidak berbau, tidak korosif, tidak beracun, dan ramah lingkungan (pradnya,2013).

Sumber Gas alam banyak terkandung didalam sumur minyak, sumur gas bumi dan tambang batubara. Dari sumber gas alam yang ada ada gas alam yang terdapat didalam minyak bumi atau batubara yang di sebut Associated gas dan ada juga gas alam yang hanya mengandung gas alam itu sendiri disebut Non Associated gas. Dari dua sumber asal gas alam yang lebih banyak yaitu di dalam golongan non associated dibandingkan associated gas (Sami matar, 2004). 
Tabel 1. Kandungan Gas Alam

\begin{tabular}{|l|}
\hline \multicolumn{1}{|c|}{ Gas Alam Terdiri Dari } \\
\hline $\mathrm{CH}_{4}($ Metana $)$ \\
\hline $\mathrm{C}_{2} \mathrm{H}_{6}$ (Etana) \\
\hline $\mathrm{C}_{3} \mathrm{H}_{8}($ Propana) \\
\hline $\mathrm{i} / \mathrm{n}_{4} \mathrm{H}_{10}($ iso/normal Butana $)$ \\
\hline $\mathrm{i} / \mathrm{n}_{5} \mathrm{H}_{12}($ Pentana $)$ \\
\hline $\mathrm{C}_{6} \mathrm{H}_{14}($ Heksana $)$ \\
\hline $\mathrm{C}_{7} \mathrm{H}_{16}($ Heptana $)$ \\
\hline $\mathrm{C}_{8} \mathrm{H}_{18++}($ Oktana plus $)$ \\
\hline $\mathrm{CO}_{2}($ Karbon Dioksida $)$ \\
\hline $\mathrm{H}_{2} \mathrm{O}$ (Uap Air formasi) \\
\hline $\mathrm{N}_{2}($ Nitrogen) \\
\hline $\mathrm{Hg}_{\text {gerkuri/Air Raksa })}$ \\
\hline Mercaptan \\
\hline $\mathrm{H}_{2} \mathrm{~S}$ (Asam Belerang) \\
\hline Solid Particle \\
\hline Mercaptan \\
\hline (Sumber : Gunung Sarjono,2012) \\
\hline
\end{tabular}

\section{TINJAUAN PUSTAKA}

Gas asam (sour gas) merupakan salah satu kandungan dari gas alam yang sifatnya sebagai kontaminan . Dimana gas alam mentah mengandung sejumlah karbon dioksida $\left(\mathrm{CO}_{2}\right)$, serta sulfur yang komponennya meliputi antara lain Hidrogen Sulfida $\left(\mathrm{H}_{2} \mathrm{~S}\right.$ ) dan mercaptan (Angelika ,2016).

Adanya kandungan sulfur yaitu gas hidrogen sulfida dan mercaptan dalam penggunaan skala rumah tangga merupakan zat sangat beracun dan bersifat korosif pada logam. Pada proses produksi $\mathrm{Gas}^{\mathrm{CO}_{2}}$ juga tidak diinginkan karena menjadi racun pada katalis seperti pada sintesa amoniak dan metanol, serta dapat mengurangi nilai bakar dari gas alam.

Pada saat transportasi gas $\mathrm{CO}_{2}$ akan menjadi padat (icing) seperti pada proses cryogenic pencairan gas alam . Liquefied Natural Gas (LNG) adalah gas alam yang dicairkan dengan cara didinginkan pada temperature sekitar $-160^{\circ} \mathrm{C}$ dan pada tekanan atmosfer. Proses tersebut juga untuk menghilangkan ketidak murnian dan hidrokarbon berat pada gas alam tersebut (pradnya,2013). Seperti contoh pulau natuna merupakan salah satu penghasil gas alam terbesar di indonesia disini terdapat cadangan gas bumi sebesar 50,27 TSCF. Akibat kandungan gas asam ( sour gas) yang sangat tinggi terutama $\mathrm{CO}_{2}$ mencapai mencapai $71 \%$ (umumnya hanya $1-2 \% \mathrm{CO}_{2}$ ). Pada pengolahan gas bumi, $\mathrm{CO}_{2}$ dipisahkan dari gas bumi sampai $4 \%$ untuk sales gas dan 50 ppm untuk LNG. Masalah utama dari tingginya kandungan $\mathrm{CO}_{2}$ pada gas Natuna adalah diperlukan proses separasi $\mathrm{CO}_{2}$ yang lebih kompleks serta penanganan limbah $\mathrm{CO}_{2}$ yang dapat menyebabkan pemanasan global (Kameliya.2016).

Tabel 2. Analisis gas Natuna

\begin{tabular}{|c|c|}
\hline Komponen & Komposisi \\
\hline $\mathrm{CO}_{2}$ & $71 \%$ \\
\hline $\mathrm{CH}_{4}$ dan hidrokarbon & $28 \%$ \\
\hline $\mathrm{H}_{2} \mathrm{~S}$ & $0,6 \%$ \\
\hline $\mathrm{N}_{2}$ & $0,4 \%$ \\
\hline
\end{tabular}

Sumber (Suhartono,2000) 


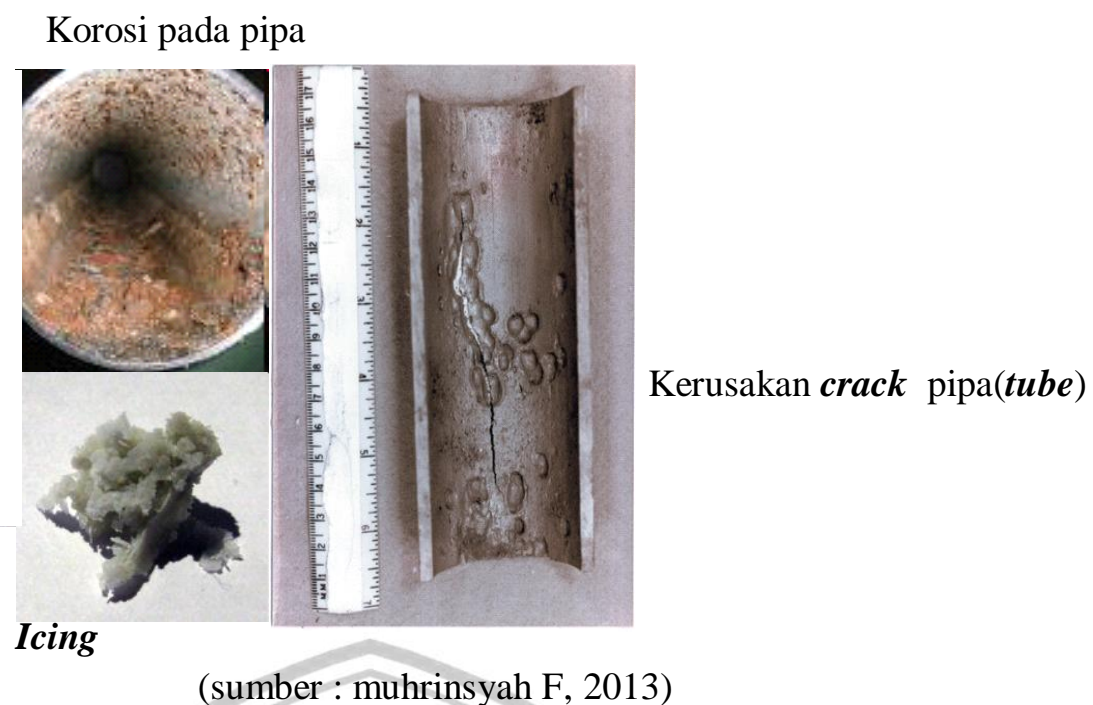

Gambar 1. Dampak yang ditimbulkan apabila ada kandungan sour gas dalam gas alam Pada Proses Produksi.

Tabel 3. Kandungan gas asam pada beberapa negara penghasil gas alam

\begin{tabular}{|c|c|c|c|c|}
\hline Parameter & Russia & Hungary & Czech & Kazakh \\
\hline Dew Point & $10^{\circ} \mathrm{C}$ & $5^{\circ} \mathrm{C}$ & $15^{\circ} \mathrm{C}$ & $25^{\circ} \mathrm{C}$ \\
\hline Tekanan & 2.7 bar & 25 bar & 3 bar & 25 bar \\
\hline $\mathrm{H}_{2} \mathrm{~S}$ & $0.5 \%$ & 0 & $2.2 \%$ & $26.5 \%$ \\
\hline $\mathrm{NH}_{3}$ & 0 & 0 & $0.89 \%$ & 0 \\
\hline $\mathrm{MeSH}$ & 0 & 0 & 0 & 0.1 \\
\hline $\mathrm{H}_{2}$ & 0 & 0 & 81 & 0 \\
\hline $\mathrm{N}_{2}$ & $16 \%$ & $5.61 \%$ & 0 & $1.2 \%$ \\
\hline $\mathrm{CH}_{4}$ & $38 \%$ & $69 \%$ & $7.5 \%$ & $35 \%$ \\
\hline $\mathrm{C}_{2} \mathrm{H}_{6}$ & $18.2 \%$ & $2.64 \%$ & $3 \%$ & $17 \%$ \\
\hline $\mathrm{C}_{3} \mathrm{H}_{8}$ & $16.5 \%$ & $1.17 \%$ & $2.7 \%$ & $12 \%$ \\
\hline $\mathrm{i}-\mathrm{C}_{4} \mathrm{H}_{10}$ & $4.8 \%$ & $0.26 \%$ & $1 \%$ & $2.3 \%$ \\
\hline $\mathrm{n}-\mathrm{C}_{4} \mathrm{H}_{10}$ & $2.3 \%$ & $0.43 \%$ & $1 \%$ & $2.3 \%$ \\
\hline $\mathrm{i}-\mathrm{C}_{5} \mathrm{H}_{12}$ & $1 \%$ & $0.15 \%$ & 0 & $0.5 \%$ \\
\hline $\mathrm{n}-\mathrm{C}_{5} \mathrm{H}_{12}$ & $1 \%$ & $0.14 \%$ & 0 & $0.35 \%$ \\
\hline $\mathrm{n}-\mathrm{C}_{6} \mathrm{H}_{4}$ & $0.5 \%$ & $0.14 \%$ & 0 & $0.15 \%$ \\
\hline $\mathrm{n}-\mathrm{C}_{7} \mathrm{H}_{16}$ & 0 & $0.09 \%$ & $0.5 \%$ & 0 \\
\hline $\mathrm{n}-\mathrm{C}_{8} \mathrm{H}_{18}$ & 0 & 0 & $0.2 \%$ & 0 \\
\hline $\mathrm{n}-\mathrm{C}_{9} \mathrm{H}_{20}$ & 0 & 0 & 0.01 & 0 \\
\hline
\end{tabular}

Sumber ( luke Addington,2014).

\section{PROSES PENGOLAHAN SOUR GAS}

Adanya kandungan gas $\mathrm{CO}_{2}$ dan $\mathrm{H}_{2} \mathrm{~S}$ yang tinggi didalam gas alam perlu dilakukan treatment khusus dalam menghilangan kandungan gas asam (sour gas) tersebut dari gas alam dimana proses penghilangan gas asam dari gas alam disebut proses Sweetening gas. Dimana perbedaan proses sweetening gas itu berdasarkan kandungan gas asam (sour gas) yang terdapat didalam gas alam baik secara kualitas maupun kuantitas dimana gas asam yang akan dihilangkan yaitu : hanya mengandung gas $\mathrm{CO}_{2}$, saja, hanya mengandung gas $\mathrm{H}_{2} \mathrm{~S}$ saja, Mengandung kedua-duanya yaitu $\mathrm{H}_{2} \mathrm{~S}$ dan $\mathrm{CO}_{2}$, yang hanya selektif menghilangkan gas $\mathrm{H}_{2} \mathrm{~S}$ walaupun keduanya yaitu $\mathrm{H}_{2} \mathrm{~S}$ dan $\mathrm{CO}_{2}$ terdapat dalam gas 
alam (Total finaelp,2002). Proses Penanganan Gas Asam (Sour Gas) Yang Terkandung Dalam Gas Alam Menjadi Sweetening Gas dapat dilakukan dalam beberapa proses sebagai berikut (Total finelp,2002) :

1. Absorpsi Kimia

2. Absorpsi Fisik

3. Absorpsi Fisik-Kimia

4. Adsorpsi Fisik

5. Fraksinasi Cryogenic

6. Permeation (membran)

7. Konversi sulfur dengan metode direct proses

\section{Absorpsi Kimia}

Absorbsi gas merupakan proses kontak antara campuran gas dan cairan yang bertujuan menghilangkan salah satu komponen gas dengan cara melarutkannya menggunakan cairan yang sesuai. Proses absorbsi ini melibatkan difusi partikel-partikel gas ke dalam cairan. Secara umum, faktor-faktor yang mempengaruhi absorbsi adalah kelarutan (solubility) gas dalam pelarut dalam kesetimbangan, tekanan operasi, serta temperature ( Sutrasno,2007).

Beberapa pelarut kimia tersedia untuk proses sweetening gas dalam absorpsi kimia ini, hampir semuanya merupakan produk golongan alkanolamin. Semua digunakan dalam bentuk larutan cairan. Produk alkanolamine utama yang digunakan dalam industri proses sweetening gas adalah sebagai berikut ( Total fina Elf,2002) :

- Mononethanolamine (MEA)

- Diglycolamine (DGA)

- Diethanolamine (DEA)

- Diisopropanolamine ( DIPA)

- Methyldiethanolamine (MDEA)

Atau ada golongan alkaline sebagai alternative absorben Potasium Karbonat $\left(\mathrm{K}_{2} \mathrm{CO}_{3}\right)$

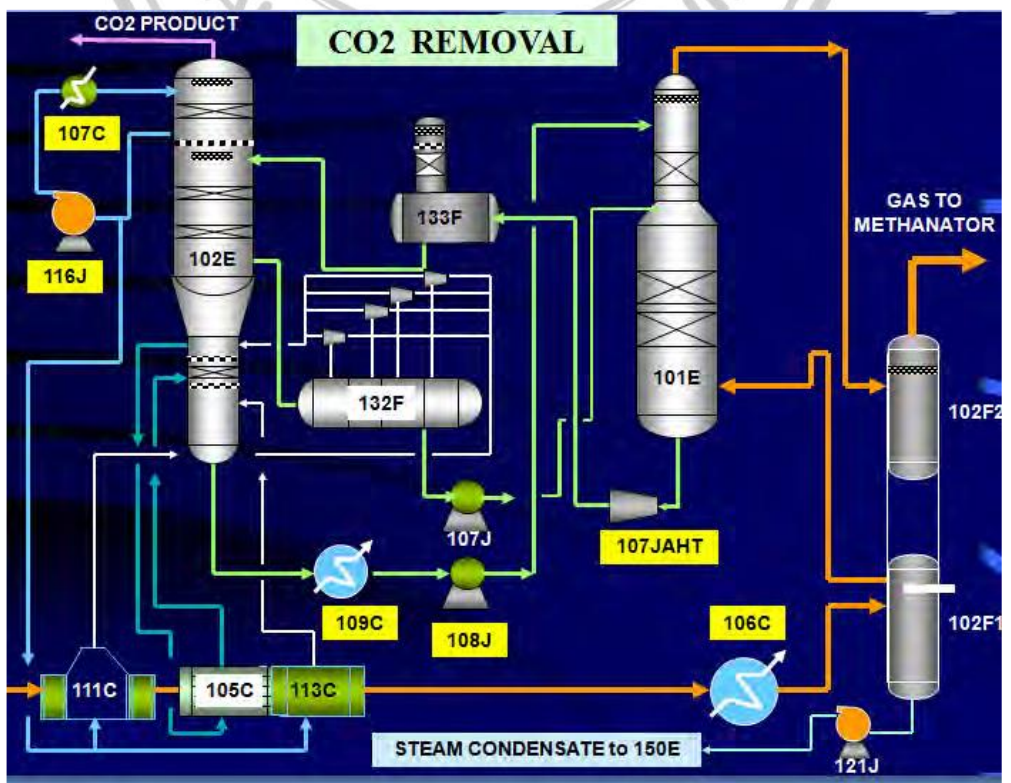

(Sumber :petrokimia gresik,Revi 2014)

Gambar 2. Penanganan sour gas menggunakan absorpsi kimia menggunakan potassium karbonat $\left(\mathrm{K}_{2} \mathrm{CO}_{3}\right)$. 
Reaksi yang terjadi dalam absorpsi kimia :

Penggunaan Potasium karbonat sebagai absorben reaksi yang terjadi sebagai berikut :

$\mathrm{H}_{2} \mathrm{O}_{(\mathrm{l})}+\mathrm{K}_{2} \mathrm{CO}_{3}(\mathrm{l})+\mathrm{CO}_{2}(\mathrm{~g}) \quad 2 \mathrm{KHCO}_{3}(\mathrm{l})$

Terbentuknya $2 \mathrm{KHCO}_{3}$ (1) pada proses absopsi kimia ini mudah untuk diregenerasi menggunakan stripper. Reaksi absorpsi eksotermik: Panas reaksi $\mathrm{K}_{2} \mathrm{CO}_{3}$ dengan $\mathrm{CO}_{2}$ adalah $32 \mathrm{BTU} / \mathrm{SCF} . \mathrm{CO}_{2}$ (1191 kJ / Sm ${ }^{3} \mathrm{CO}_{2}$ ). Karbonat diubah menjadi bikarbonat selama siklus penyerapan. Selama regenerasi siklus, bikarbonat sekali lagi diubah menjadi karbonat setelah $\mathrm{CO}_{2}$ dihilangkan (pada kenyataannya, semua bikarbonat tidak dikonversi menjadi karbonat). Pada golongan alkanolamine seperti larutan MEA digunakan untuk menghilangkan $\mathrm{CO}_{2}$ secara mendalam (ketika gas umpan bebas dari $\mathrm{H}_{2} \mathrm{~S}$ ), $\mathrm{H}_{2} \mathrm{~S}$ (ketika gas umpan bebas dari $\mathrm{CO}_{2}$ ) atau $\mathrm{H}_{2} \mathrm{~S}$ dan $\mathrm{CO}_{2}$ ketika kedua komponen ada dalam Gas alam umpan. Oleh karena itu ini bukan proses yang cocok untuk penghilangan selektif $\mathrm{H}_{2} \mathrm{~S}$ ketika keduanya $\mathrm{H}_{2} \mathrm{~S}$ dan $\mathrm{CO}_{2}$ ada dalam gas alam.

MEA akan dengan mudah mengurangi konsentrasi $\mathrm{H}_{2} \mathrm{~S}$ menjadi kurang dari 4 ppm dalam alam . Namun, amina ini bereaksi dengan produk sulfur turunan seperti karbonil sulfida (COS) dan karbon disufida $\left(\mathrm{CS}_{2}\right)$, karena itu diperlukan peralatan khusus untuk membersihkan larutannya .

Jika merkaptan ada dalam gas umpan, larutan MEA hanya akan menghilangkan sebagian saja kontaminan ini dengan prioritas diberikan pada mercaptans ringan (metil-merkaptan).

$\mathrm{H}_{2} \mathrm{~S}$ bereaksi lebih cepat daripada $\mathrm{CO}_{2}$.

Reaksi dengan $\mathrm{H}_{2} \mathrm{~S}$ dilanjutkan untuk membentuk bisulfida etanolamin.

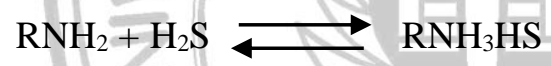

Penyerapan kimiawi $\mathrm{CO}_{2}$ lebih kompleks. Karbon dioksida bereaksi dengan MEA untuk terbentuk garam karbamat (sulit atau regenerasi dan yang dapat menyebabkan masalah korosi):

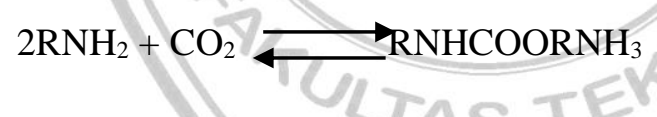

Dalam larutan air, asam organik $\left(\mathrm{CO}_{2}+\mathrm{H}_{2} \mathrm{O}\right)$ bereaksi dengan MEA untuk membentuk garam bikarbonat (lebih mudah untuk regenerasi):

$$
\mathrm{RNH}_{2}+\mathrm{H}_{2} \mathrm{O}+\mathrm{CO}_{2} \rightleftarrows \mathrm{RNH}_{3} \mathrm{HCO}_{3}
$$

di mana $\mathrm{R}=\mathrm{C}_{2} \mathrm{H}_{4} \mathrm{OH}$

Reaksi di atas bersifat reversibel. Kiri ke arah kanan reaksi mewakili fase penyerapan (lebih baik pada suhu rendah dan tekanan tinggi). Ini adalah reaksi eksotermis terjadi pada alat absorber .

Kanan ke arah kiri reaksi mewakili fase regenerasi (lebih baik pada tinggi suhu dan tekanan rendah). Ini adalah reaksi endotermik terjadi pada alat stripper.

Pada Gambar 3. diagram proses absorpsi sour gas yang dikembangkan oleh Exxon mobil menggunakan solvent yang selective menghilangkan gas $\mathrm{CO}_{2}$ dan $\mathrm{H}_{2} \mathrm{~S}$ yang telah diaplikasikan pada pengolahan gas alam di onshore dan offshore. Ada dua jenis solvent yang Exxon mobil yaitu FLEXSORB SE Selective menghilangkan gas $\mathrm{H}_{2} \mathrm{~S}$ dan FLEXSORB SE Plus Selective removal of $\mathrm{H}_{2} \mathrm{~S}$ to less than $10 \mathrm{ppm}$. 


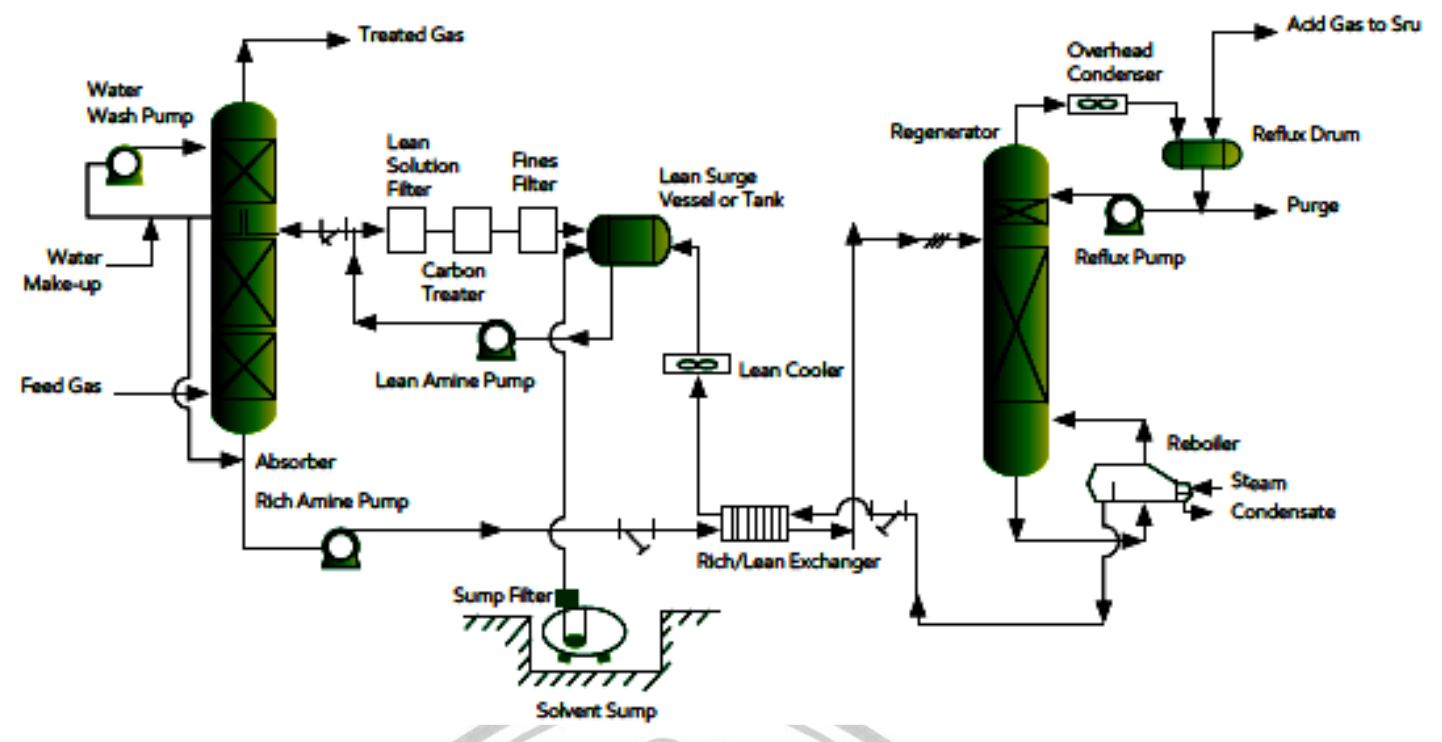

Gambar 3 .Proses absorbsi sour gas menggunakan pelarut amine FLEXSORB® SE Tail Gas Treating Unit (Exxon Mobil.2015)

Tabel 1. Hasil Absorpsi Kimia sour gas Menggunakan Proses Flexsorb SE

\begin{tabular}{|l|c|c|}
\cline { 2 - 3 } \multicolumn{1}{c|}{} & Conventional Hybrid & Flexsorb SE \\
\hline Sour Gas Rate, MSCFD & 400 & 510 \\
\hline Pressure, psig & 935 & 935 \\
\hline Temperature ${ }^{\circ} \mathrm{F}$ & 90 & 90 \\
\hline Feed Composition, vol \% & & \\
\hline $\mathrm{H} 2 \mathrm{~S}$ & 0.06 & 0.06 \\
\hline $\mathrm{CO} 2$ & 1 & 1 \\
\hline Solvent Rate, gpm & 460 & 300 \\
\hline Reboiler Duty, MBTU/HR & 19 & 14.8 \\
\hline Treated Gas & & \\
\hline H2S vppm & $-{ }^{2}$ & 2 \\
\hline CO2 mole \% & 0.7 & 0.85 \\
\hline
\end{tabular}

(sumber: Exxon Mobil,2015)

\section{Absorpsi Fisik}

Penghilangan gas asam dengan absorpsi fisik juga dimungkinkan dan ada sejumlah proses kompetitif secara komersial berdasarkan pada prinsip ini. Absorpsi fisik terjadi karena kontak fisik antara gas yang akan diolah dan pelarut. Pelarut digunakan sebagai produk murni. Akibatnya, air tidak perlu ditambahkan secara fisik proses penyerapan. Penyerapan fisik sangat tergantung pada tekanan gas umpan atau tekanan parsial gas asam hadir dalam gas umpan. Pelarut yang digunakan untuk sweetening gas umumnya memiliki afinitas yang kuat dengan air pelarut secara bersamaan akan membersihkan dan mengeringkan gas. Namun, penumpukan air pelarut akan terjadi membutuhkan stripper untuk menghilangkan air yang diserap dari pelarut. Penyerapan fisik bisa juga berhasil digunakan; keuntungan utama dari proses semacam itu adalah (tidak seperti penyerapan bahan kimia) pelarut fisik tidak memiliki batasan penyerapan. Jumlah $\mathrm{CO}_{2}$ yang diserap oleh pelarut adalah ditentukan oleh kesetimbangan uap-cair dari campuran, yang diatur oleh tekanan dan suhu. Pada tekanan parsial $\mathrm{CO}_{2}$ yang tinggi, kapasitas pemuatan $\mathrm{CO}_{2}$ dari pelarut lebih tinggi untuk pelarut fisik daripada pelarut kimia. Karenanya proses penyerapan fisik khususnya sesuai untuk pengolahan aliran gas kaya $\mathrm{CO}_{2}$. Pelarut untuk penyerapan fisik Banyak pelarut 
telah digunakan untuk penyerapan $\mathrm{CO}_{2}$ dan $\mathrm{H}_{2} \mathrm{~S}$ termasuk, formulasi tributil fosfat, polikarbonat, metiltias asetat, dan n-formil morfolin. Ada yang utama kelemahan dengan pelarut seperti itu: mereka tidak mudah sekali pakai untuk operasi lepas pantai (offshore) dan bisa terlibat dalam reaksi samping dengan konstituen gas alam lainnya. Pelarut hidrokarbon seperti n-butana adalah lebih cocok karena tidak bereaksi dan dapat dengan mudah ditangani di lingkungan minyak dan gas; nbutane telah digunakan dalam proses pemisahan cryogenic Ryan-Holmes. Prosesnya sudah memuaskan Faktor pemisahan $\mathrm{CO}_{2} / \mathrm{CH}_{4}$, tetapi operasi pada suhu rendah sangat menuntut energi. Seperti nbutane, alkana lain seperti n-decane diketahui menyerap $\mathrm{CO}_{2}$ secara istimewa untuk $\mathrm{CH}_{4}$ : eksperimental Temuan menunjukkan nilai-K [faktor pemisahan, $\mathrm{K}=\left(\mathrm{CO}_{2}: \mathrm{CH}_{4}\right)$ cair $/\left(\mathrm{CO}_{2}: \mathrm{CH}_{4}\right)$ gas] mulai dari 1,2 hingga 1,8 .Penggunaan alkana yang lebih tinggi atau campuran alkana dapat memberikan rute yang menjanjikan untuk beradaptasi Proses Ryan-Holmes dengan suhu dan tekanan khas ladang gas. Selain itu, alkana pelarut memberikan keuntungan karena harganya murah, mudah didapat, dan bisa digemari (campuran alkana). (Emmanuel Keskes.2011)

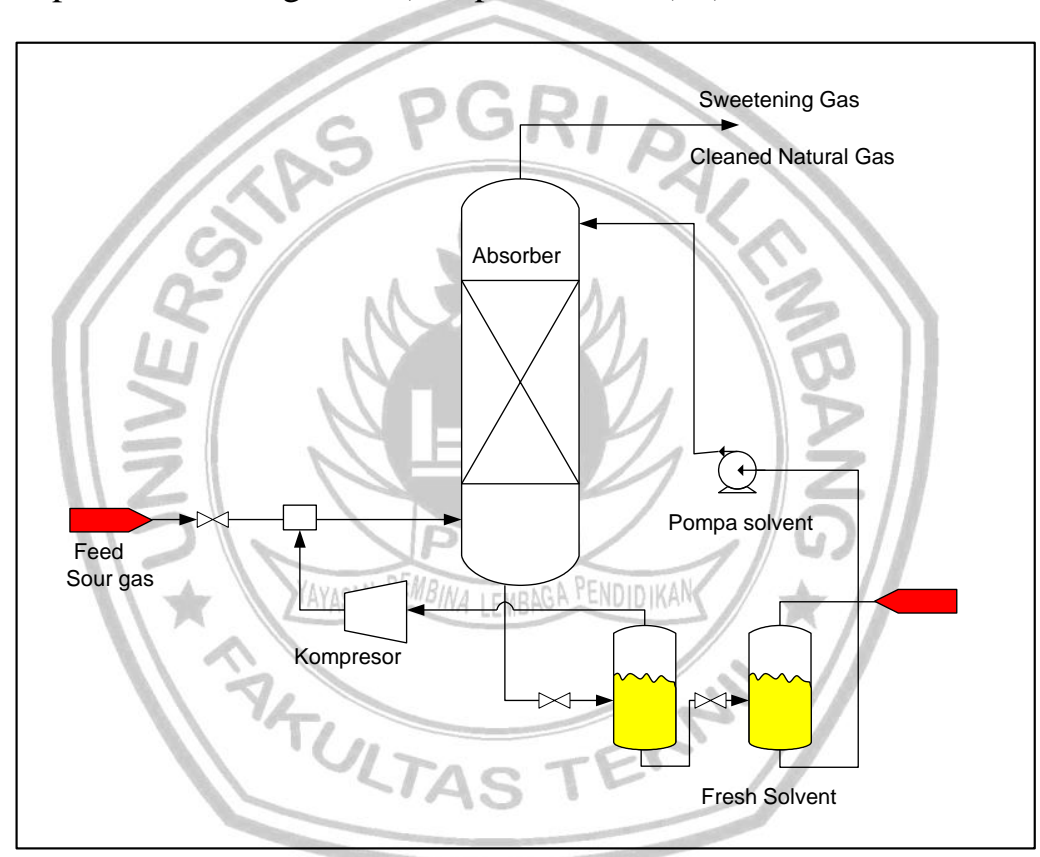

Gambar 4. Proses Absorbsi Fisika sour gas menjadi sweetening gas

Pada gambar 4. Flow sheet Absorpsi fisika untuk menangkap $\mathrm{CO}_{2}$ dari gas alam Metodologi untuk menemukan kondisi proses yang optimal dan pelarut telah dikembangkan menggunakan persamaan keadaan tingkat lanjut (SAFT-VR), perangkat lunak optimisasi pemodelan proses (gPROMS), dan estimasi biaya proses terperinci.

proses pemodelan-optimasi perangkat lunak (gPROMS), dan estimasi biaya proses rinci. Pakan gas alam yang mengandung hingga $70 \%$ mol / mol CO2 dapat diolah secara ekonomis menggunakan proses ini (Emmanuel Keskes,2011).

Berikut ini beberapa proses absorpsi fisik yang dikembangkan beberapa perusahaan gas yang memiliki referensi industri dalam Sweetening gas alam, sebagai berikut. Fluor Solven (Polypropylene Carbonate) Dari Fluor, Selexol (Dimethyl Ether Of Polyethylene Glycol) Dari Uop ,Purisol (NMethyl-Pyrrolidone) Dari Lurgi , Rectisol (Methanol) Dari Lurgi. Semua proses didasarkan pada Absorpsi fisika (kecuali air yang dapat dianggap sebagai pelarut fisik untuk pemindahan bulk $\mathrm{H}_{2} \mathrm{~S}$ dan $\mathrm{CO}_{2}$ tetapi dengan tingkat korosi yang tinggi ) berasal dari pemberi lisensi. 


\section{Proses Absorspi Kimia - Fisika}

Prinsip dari proses ini bertujuan untuk menggabungkan potensi absorspi yang tinggi dari alkanolamine (Absorpsi kimia) dan kebutuhan energi regenerasi rendah dari pelarut fisika (absorpsi fisika). Peneltian tentang sour gas menjadi sweeteaning Gas dari gas Alam dengan absorpsi campuran terhadapa kelarutan Etana, Karbon Dioksida, dan Hidrogen Sulfida dalam Campuran dengan absorpsi pelarut secara Fisik dan Kimia Kelarutan etana, karbon dioksida, dan hidrogen sulfida telah terjadi diukur dalam propilena karbonat, N-metil-2-pirolidon dan tetrametilen sulfon (sulfolana); dan dalam campuran pelarut fisik ini dengan monoethanolamine dan diglycolamine, dalam kisaran -10 hingga $100^{\circ} \mathrm{C}$. Termodinamika persamaan yang konsisten diberikan untuk penyerapan gas dengan bahan kimia reaksi pada kesetimbangan. Hukum Henry menggambarkan keseimbangan fisik antara gas asam dalam fase uap dan asam terlarut dalam fase cair. Konstanta kesetimbangan menggambarkan kesetimbangan kimia untuk gas yang diserap dan pelarut kimia. Perhitungan desain awal untuk memaniskan gas alam dengan penyerapan dengan pelarut campuran menunjukkan bahwa, dalam beberapa keadaan, campuran solven penyerapan mungkin lebih ekonomis daripada menggunakan air konvensional alkanolamin (O.rivas, 1979). Proses Hybrisol seperti yang ditunjukkan pada gambar 4 di bawah ini adalah untuk menggabungkan unit penghilangan gas asam berdasarkan MDEA di solusi metanol dan proses dingin untuk pemulihan LPG atau titik embun. Dalam penghilangan gas asam , gas jenuh dalam metanol yang membantu untuk menghambat hidrida dalam proses dingin dan proses dingin memulihkan metanol dengan kondensasi. Dalam stripper metanol, gas jenuh dalam metanol dengan stripping campuran methanol dan air yang dikeluarkan dari LTS. Proses ini sangat mirip dengan IFPEX 1. Penghilangan gas asam ditunjukkan pada gambar 4. Dimana beroperasi dengan campuran metanol, air dan MDEA dan skema prosesnya serupa dengan proses regenerasi amina apa pun kecuali cold drum yang ada pada bagian atas kolom regenerasi untuk recovery metanol.

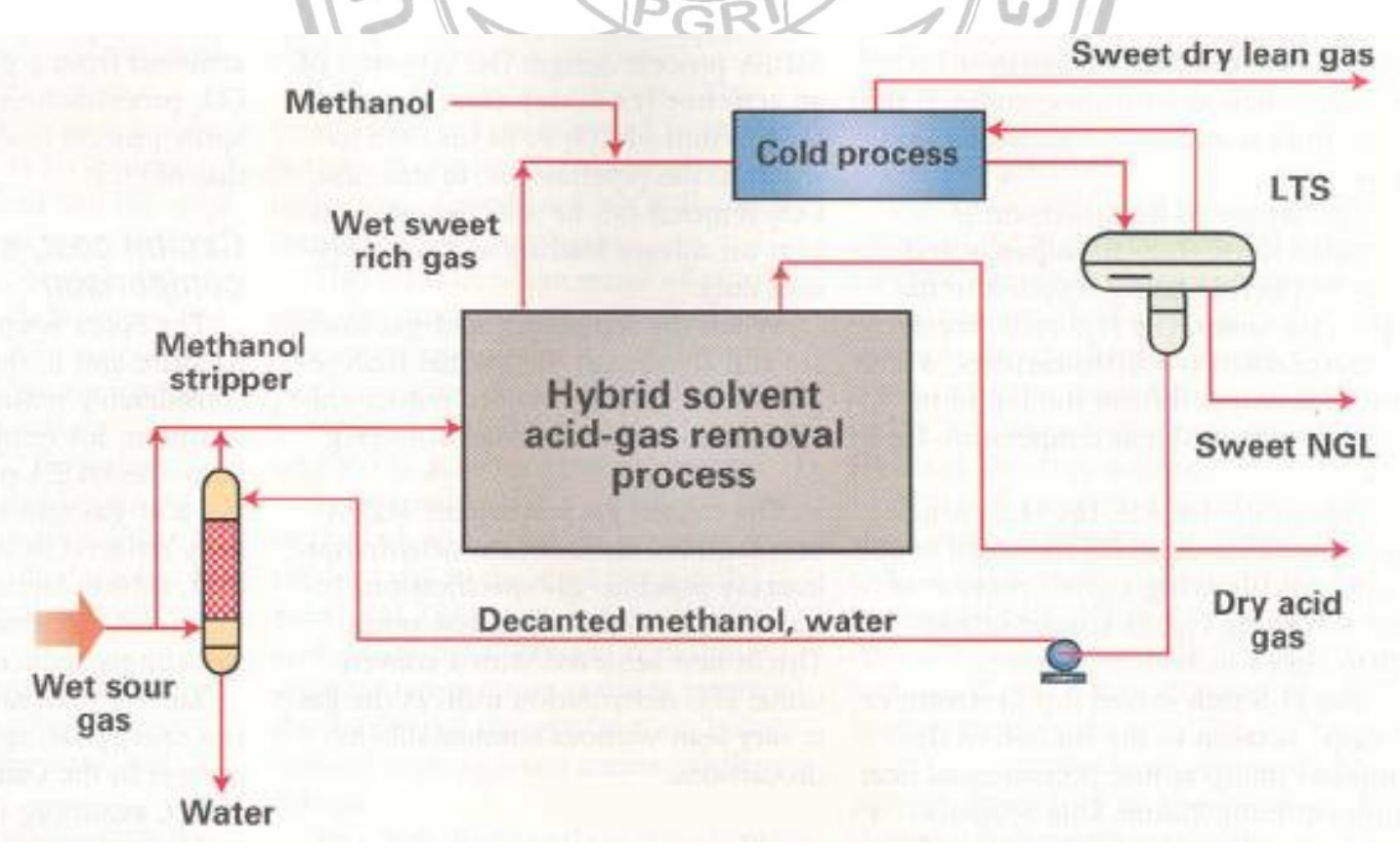

Gambar 4. Proses absorpsi Kimia -Fisika menggunakan proses Hybrisol

\section{Adsorption Fisik}

Peristiwa adsorbsi dapat terjadi pada adsorben yang pada umumnya beberapa zat padat. Adsorpsi adalah salah satu proses penyerapan dimana suatu cairan atau gas akan terikat pada suatu padatan atau cairan (absorben) dan membentuk lapisan film (adsorbat) pada permuakaannya. Adsorpsi fisik 
berkaitan dengan penggunaan bagaimana menghilangkan gas asam dengan menyaringan molekuler gas tersebut . Proses ini tidak cocok untuk menghilangkan sejumlah besar gas asam yang ada di dalam gas alam . Itu hanya dapat untuk menghilangakan hanya dalam batas ppm dari $\mathrm{H}_{2} \mathrm{~S}$ atau $\mathrm{CO}_{2}$. Proses ini bisa menghilangakan gas sulfur yang masih ada pada pada penghilangan gas sulfur pada umpan gas ( mercaptan) pada proses sebelumnya.

Penelitian yang dilakukan oleh (Carlos,2017) Gas alam (NG) adalah bahan bakar fosil dengan emisi $\mathrm{CO}_{2}$ terendah per kilowatt energi yang dihasilkan. Dalam hal pengangkutan gas alam melalui pipa, spesifikasi $\mathrm{CO}_{2}$ tergantung pada masing-masing negara tetapi sekitar $2-4 \%$, jadi dalam kasus itu alami gas mengandung lebih dari persentase ini, $\mathrm{CO}_{2}$ harus dikeluarkan untuk memenuhi spesifikasi. Dalam studi ini, kami telah mengevaluasi kelayakan menggunakan proses Pressure Swing Adsorption (PSA) untuk menghilangkan karbon dioksida dari gas alam. Proses ini belum tersedia secara komersial dan karenanya menghadapi beberapa tantangan terkait pemanfaatan bahan yang tepat dan skema regenerasi yang efisien. Studi kami telah mempertimbangkan efek dari proses PSA yang berbeda mode operasi.

Unit PSA dirancang untuk meningkatkan gas alam dengan komposisi $83 \% \mathrm{CH}_{4}, 10 \% \mathrm{CO}_{2}$ dan $7 \% \mathrm{C}_{2} \mathrm{H}_{6}$ tersedia pada 70 bar pada suhu $313 \mathrm{~K}$ dan dengan debit masuk $500.000 \mathrm{Sm}^{3} / \mathrm{jam}$. Analisis juga mempertimbangkan beberapa hal variabel proses. Perbandingan ekonomi dari harga Adsorpsi juga telah dilakukan. Analisis kami menunjukkan bahwa biaya adsorpsi $\mathrm{CO}_{2}$ menggunakan PSA sekitar 40\% lebih tinggi daripada menggunakan amina yang didominasi oleh kinerja yang buruk dalam proses pemulihan ( kehilangan gas alam dengan $\mathrm{CO}_{2}$ ). Karena ini adalah studi pertama dari jenisnya, ada banyak ruang untuk meningkatkan kinerja proses dan adsorpsi itu proses untuk aplikasi ini tidak hanya terbatas pada konsentrasi yang sangat rendah. (Carlos,2017)

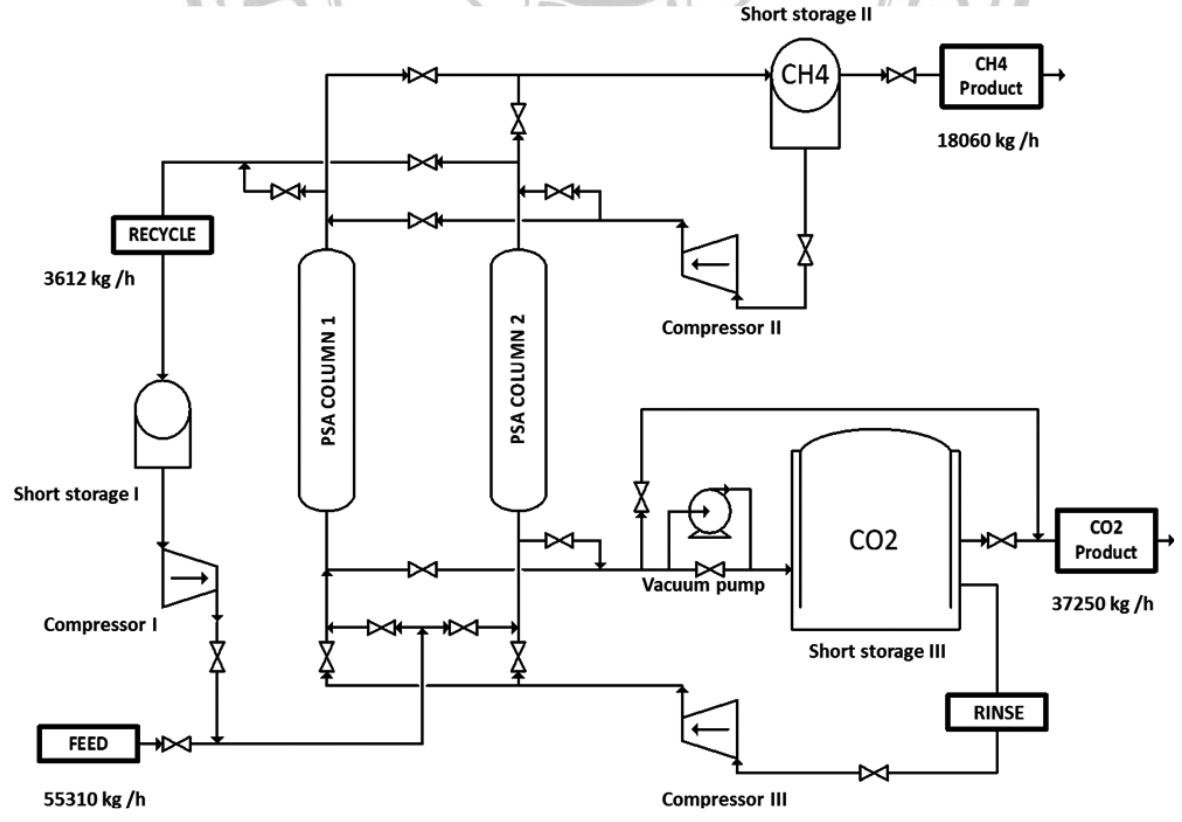

Gambar 5. Proses adsorption fisik dengan proses Pressure Swing Adsorption (PSA)

Pada gambar 5. merupakan proses adsorpsi menggunakan proses Pressure Swing Adsorption (PSA) menggunakan sebagai adsorben logam-organik $\mathrm{NH}_{2}-\mathrm{MIL}-53(\mathrm{Al})$ untuk mengadsorpsi $\mathrm{CO}_{2}$ dari $\mathrm{Gas}_{\mathrm{CH}}$ yang terdapat dalam gas alam. Di antara alternatif yang dipertimbangkan, Pressure Swing Adsorption dengan kondisi operasi vakum dipilih dalam fase desain ini . Dengan mengkondisikan kombinasi desain dengan kolom secara paralel dan kemungkinan sirkulasi ulang 
beberapa aliran memastikan tingkat pemisahan $\mathrm{CO}_{2}$ dari gas metan yang tinggi dan produk akhir dengan kualitas tinggi tanpa mengurangi biaya operasi. (Pablo Serra-Crespo,2015).

\section{Fraksinasi Cryogenic}

Secara konvensional, Sour gas aliran gas alam diserap menggunakan absorben golangan amina atau larutan kimia lain yang sesuai, teradsorpsi atau dipisahkan dengan menggunakan permeasi membran. Namun, jika kandungan sour gas dalam gas alam tinggi, berarti keekonomis proses yang ada perlu dikembangkan menjadikannya lebih hemat biaya dan pengembangan proses baru menjadi keharusan.

Proses fraksinasi criogenik merupakan alternative proses untuk pemisahan sour gas yang kandungannya tinggi dalam gas alam yang beroperasi pada suhu rendah dan tekanan tinggi untuk memisahkan sour gas Teknologi pemisahan kriogenik bisa diklasifikasikan menjadi :

1. Metode kriogenik konvensional atau distilasi berbasis uap-cair dan distilasi ekstraktif teknologi.

2. Metode non-konvensional, yang termasuk teknologi baru seperti desublimasi uap padatberdasarkan pemisahan, sentrifugal kontaminan terkondensasi pemisahan, kompresi ulang,dan cryocooler seperti pengaduk pendingin.

3. Teknologi hybrid

Teknologi yang menggabungkan dengan memaksimalkan proses dari teknologi konvensional dan non-konvensional.

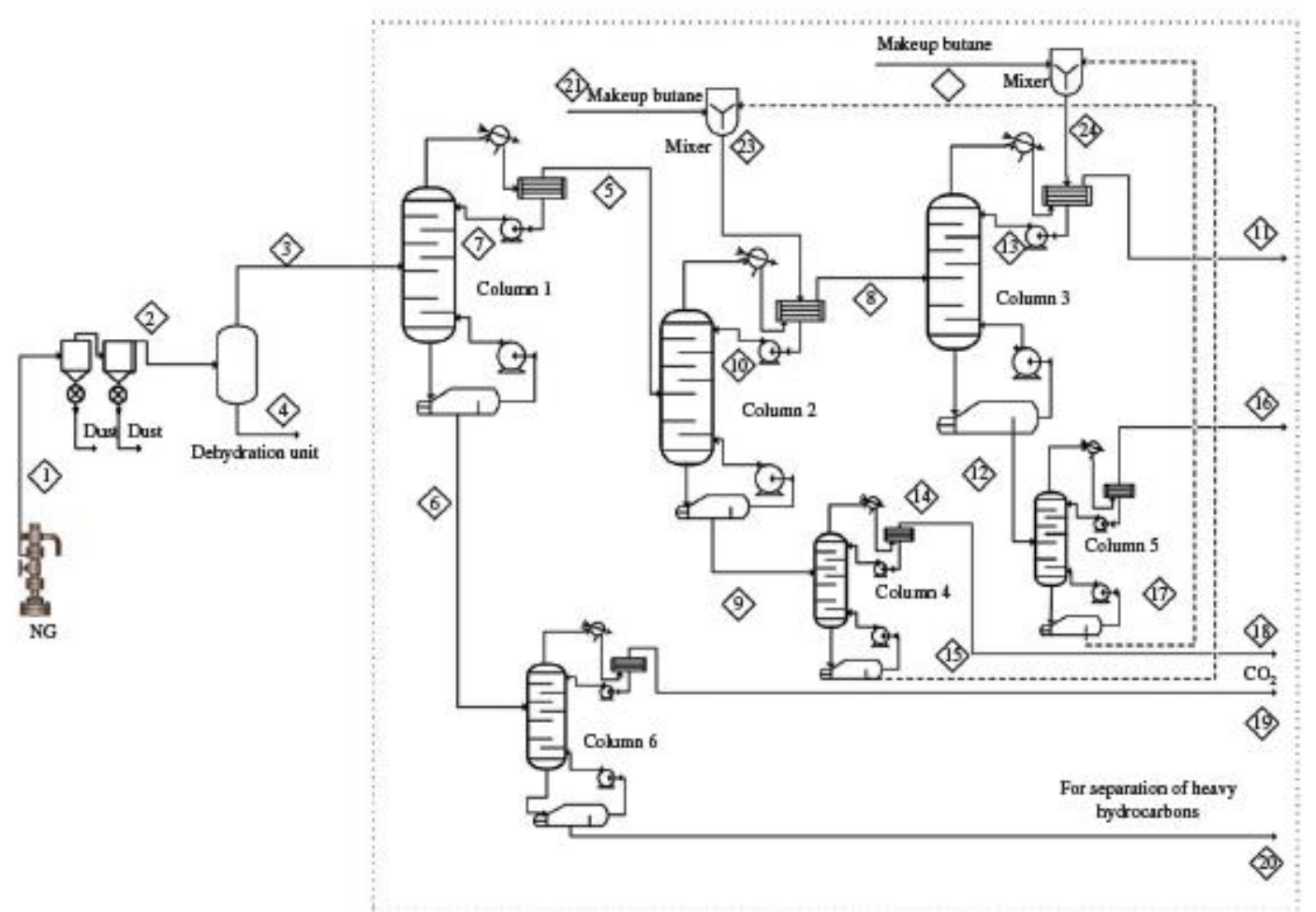

Gambar 7. Proses Cryogenic Karbon Dioksida dari gas alam

\section{Permeation (membran)}

Membran polimer (yang tidak mengandung lubang atau pori) bukanlah teknologi baru untuk pemisahan gas. Pemisahan ini didasarkan pada prinsip bahwa senyawa gas tertentu larut dan berdifusi bahan polimer pada tingkat yang lebih cepat daripada yang lain. Karbon dioksida, hidrogen, helium, hidrogen sulfida dan uap air sangat permeabel (gas cepat). Sebaliknya, nitrogen, metana dan Senyawa parafin yang lebih berat kurang permeabel (gas lambat). Aplikasi terbaik untuk pemisahan membran 
adalah untuk memisahkan gas dalam kategori pemisahan cepat atau (Permeate) dari gas di pemisahan menjadi lambat ( Residue Gas ). Misalnya, $\mathrm{CO}_{2}$ akan melewati membran polimer 15 sampai 40 kali lebih cepat dari metana ( Total,2002)

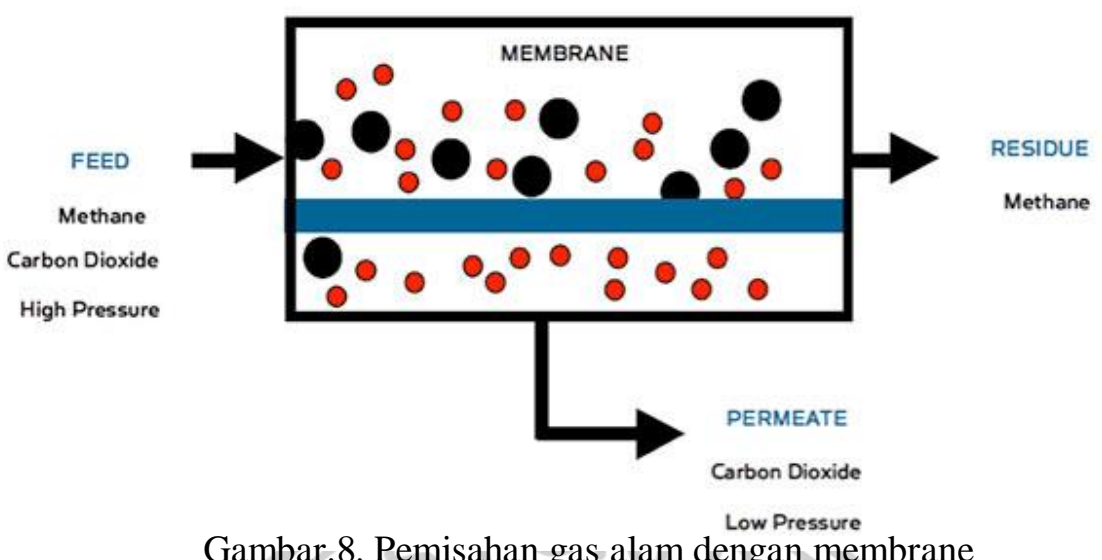

Banyak keuntungan yang diperoleh dari penggunaan teknologi membran seperti ( Kevin,2016 ) :

- Biaya investasi modal yang rendah

- Praktis

- Mudah dalam proses instalisasi dan pengoperasian

- Biaya perawatan yang murah

- Tidak boros tempat

- Fleksibilitas proses yang tinggi

Meski demikian, teknologi membran juga memiliki sedikit kekurangan seperti:

- Fluks permeasi yang rendah,

- Permselektivitas yang kurang memadai

- Adanya fouling membran.

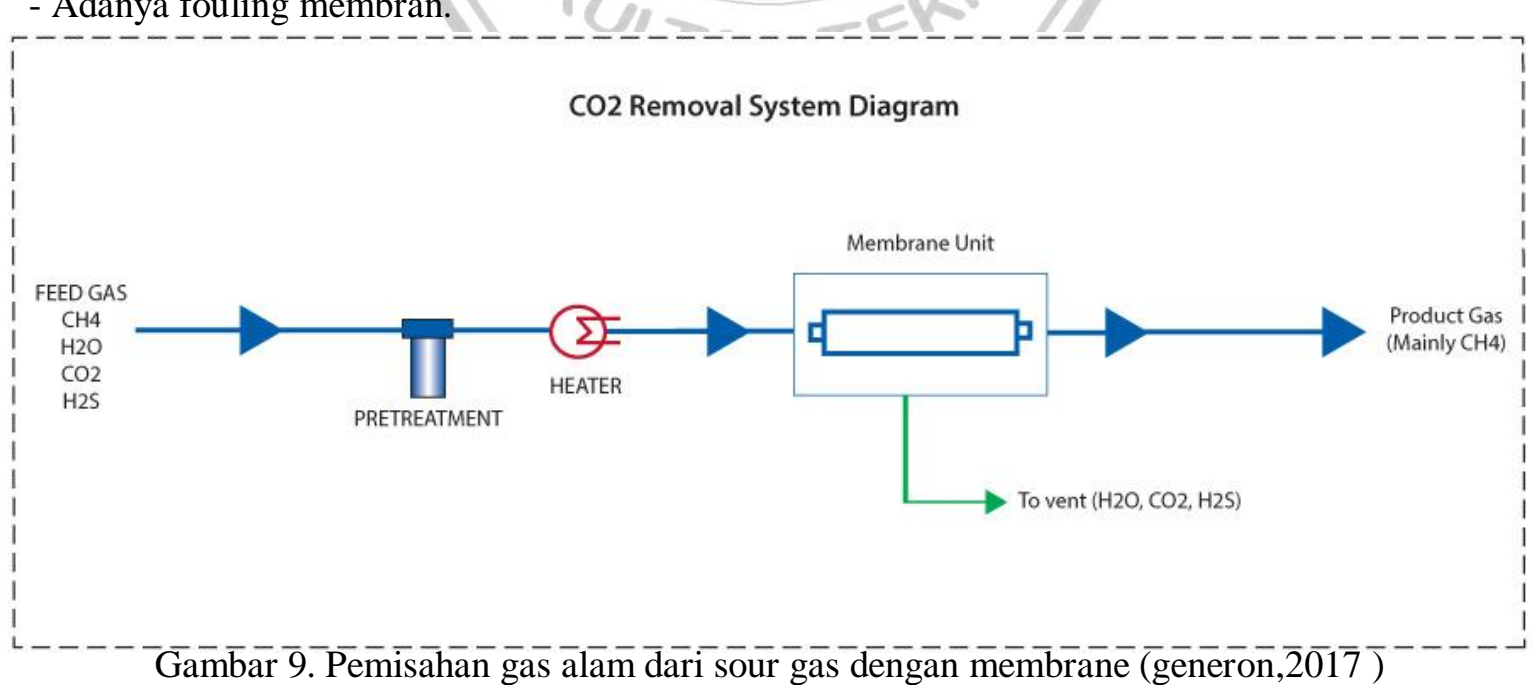

Pada gambar 8. pemisahan dengan membrane proses dimana kandungan $\mathrm{CO}_{2}$ yang tinggi dalam gas alam dalam feed > $60 \mathrm{vol} \% \mathrm{CO}_{2}$, feed gas dengan tekanan 1,000 psig (69 bar) dengan laju alir 0.01 - $500 \mathrm{MMscfd}$, dimana hasil pemisahanan setelah dikontakan dengan membrane didapat $\mathrm{CO}_{2}$ yang masih tersisa dalam kandungan gas alam $<2 \% \mathrm{CO}_{2}$ jadi untuk $>95 \%$ recovery gas methane dan > 95\% $\mathrm{CO}_{2}$ dapat dihilangkan dalam gas alam.(Generon,2017). 


\section{Konversi Sulfur Dengan Metode Direct Proses}

Proses ini umumnya digunakan untuk menghilangkan sejumlah kecil $\mathrm{H}_{2} \mathrm{~S}$ dari aliran gas alam (Dimana Konsentrasi dinyatakan sebagai ppm) dan melibatkan konversi langsung $\mathrm{H}_{2} \mathrm{~S}$ menjadi sulfur. jumlah $\mathrm{CO}_{2}$ dihilangkan. didasarkan pada konversi langsung $\mathrm{H}_{2} \mathrm{~S}$ menjadi belerang oleh katalis berbasis besi. Larutan ferric bersentuhan dengan gas di absorber dan $\mathrm{H}_{2} \mathrm{~S}$ langsung direduksi menjadi belerang (total fina ELF, 2002):

$$
\begin{aligned}
& \mathrm{H}_{2} \mathrm{~S}+2 \mathrm{Fe}^{3}+(\mathrm{L}) \longrightarrow 2 \mathrm{H}^{+}+\mathrm{S}^{0}+2 \mathrm{Fe}^{2+}(\mathrm{L}) \\
& \mathrm{L}=\text { chelaton }
\end{aligned}
$$

Solusinya diregenerasi pada tekanan rendah oleh aliran oksigen sesuai dengan reaksi:

$$
\begin{gathered}
1 / 2 \mathrm{O}_{2}+\mathrm{H} 2 \mathrm{O}+2 \mathrm{Fe}^{2+}(\mathrm{L}) \longrightarrow 2 \mathrm{OH}+2 \mathrm{Fe}^{3+}(\mathrm{L}) \\
\mathrm{H}^{+}+\mathrm{OH}^{-} \longrightarrow \mathrm{H}_{2} \mathrm{O}
\end{gathered}
$$

Reaksi keseluruhan konversi sulfur: $\mathrm{H}_{2} \mathrm{~S}+1 / 2 \mathrm{O}_{2} \longrightarrow \mathrm{H}_{2} \mathrm{O}+\mathrm{S}^{\circ}$

Sehingga sulfur berdiri sendiri menjadi unsur.

\section{KESIMPULAN}

- Penangan sour gas menjadi Yang Terkandung Dalam Gas Alam Menjadi Sweetening Gas sangat penting dilakukan dikarenakan gas asam dapat menimbulkan permasalah pada proses pengolahan gas alam selanjutnya sifat sour gas yang korosif dan merupakan racun pada katalis,menurunkan heating value serta apabila gas alam dilakukan pencairan dapat menyebabkan icing pada pipa proses sehingga menghambat laju proses pencairan gas alam.

- Pemilihan proses yang tepat dalam penanganan sour gas menjadi Sweetening Gas tergantung pada kandungan besar kecil kandungan sour gas yang ada dalam gas alam itu sendiri . Kandungan sour gas $>10 \%$ penanganan menggunakan proses Absorpsi Kimia Absorpsi Fisik, Absorpsi Fisik-Kimia, Adsorpsi Fisik, konversi sulfur secara langsung .sedangkan untuk penanganan sour gas yang memiliki $>60 \%$ menggunakan proses Fraksinasi Cryogenic ,Permeation (membrane).

\section{DAFTAR PUSTAKA}

- Angelika Permatasari, Faisal Harris, Utik Dwi Pratiwi. Teknologi Pengolahan Gas Alam.Gas Alternatif Energi Ramah LIngkungan .engineer weekly.No.03 April 2016.

- Carlos A. Grande, Simon Roussanaly, Rahul Anantharaman, Karl Lindqvist , Prachi Singh , Jasmin Kemper. CO2 Capture in Natural Gas Production by Adsorption Processes Energy Procedia 114 ( 2017 ).

- Emmanuel Keskes, Claire S. Adjiman*, Amparo Galindo, and George Jackson. 2011. A Physical Absorption Process For The Capture Of $\mathrm{CO}_{2}$ From $\mathrm{CO}_{2}$-Rich Natural Gas Streams. Chemical Engineering Department, Imperial College London,London SW7 2AZ, United Kingdom

- ExxonMobil.2015. Solutions for sour gas treating problems. Flexsorb ${ }^{\mathrm{TM}}$ Technology.

- Generon . 2017. Carbon Dioxide, $\mathrm{CO}_{2}$ Separation Tomball Parkway Houston, $T X$ 77086, USA 
- Gunung Sardjono Hadi. Pengembangan LPG Plant PT Pertamina Gas: Proses Bisnis, Peluang \& Tantangan diMasa Depan. Presented on One-Day Course: Petroleum Industry Down stream Society Of Petroleum Engineers, Gadjah Mada University Student Chapter Yogyakarta, November $10^{\text {th }}, 2012$.

- Kameliya Hani Millati, Widodo Wahyu Purwanto.2016. Pengembangan Gas Bumi Natuna $\mathrm{CO}_{2}$ Tinggi Dengan Teknologi Lng-Eor-Ccs. Perbandingan Membran Dan Cfz Untuk Separasi $\mathrm{CO}_{2}$.Jakarta Universitas Indonesia.

- Kevin Sutanto. Teknologi Membran dalam Pengolahan Gas Alam. 27 June 2016.

- Luke Addington and Chris Ness .2014.An Evaluation of General "Rules of Thumb" in Amine Sweetening Unit Design and Operation Bryan Research and Engineering, Inc Bryan, Texas, USA.

- Muhrinsyah Fatimura.2013.Absorpsi $\mathrm{CO}_{2}$ Dalam Gas Alam Menggunakan Larutan Kalium Karbonat $\left(\mathrm{K}_{2} \mathrm{CO}_{3}\right)$ Dengan Promotor Metil Dietanol Amin (MDEA). Vol 4, No 3 (2013): Kinetika .Jurnal Teknik Kimia Polsri .

- Pablo Serra-Crespo1,2,Tim A. Wezendonk1,Carlos Bach-Samario,Nishanth Sundar,Karlijn Verouden,Matthijs Zweemer,Jorge Gascon,Henk van den Berg,Freek Kapteijn. Preliminary Design of a Vacuum Pressure Swing Adsorption Process for Natural Gas Upgrading Based on Amino-Functionalized MIL-53. Chem. Eng. Technol. 2015,38, No. 7

- Pradnya A. Putri, Shinta S. Hajar, Gede Wibawa dan Winarsih . Plant Design of Cluster LNG (Liquefied Natural Gas) in Bukit Tua Well, Gresik Jurusan Teknik Kimia, Fakultas Teknologi Industri, Institut Teknologi Sepuluh Nopember (ITS). Juurnal Teknik Pomits Vol. 2, No. 1. 2013 ISSN: 2337-3539 (2301-9271 Print).

- 0. Rivas. Rlvasand and J. M. PRAUSNITZ Sweetening of Sour Natural Gases by MixedSolvent Absorption: Solubilities of Ethane, Carbon Dioxide, and Hydrogen Sulfide in Mixtures of Physical and Chemical Solvents. Chemical Engineering Department University of California Berkeley, California 94720. AlChE Journal (Vol. 25, No. 6) November, 1979.

- Revi Adikharisma.Analisis Kinerja Proses $\mathrm{CO}_{2}$ Removal Pada Kolom Absorber Di Pabrik Amoniak Unit 1 PT. Petrokimia Gresik.Jurusan Teknik Fisika Fakultas Teknologi IndustriInstitut Teknologi Sepuluh Nopember Surabaya 2014.

- Sami Matar Lewis F. Hatch.Chemistry of petrochemical processes. Gulf Publishing Company Houston, Texas, 2004.

- Sumartono.Pengolahan Gas Limbah Proyek Gas Natuna Jurnal Teknologi Lingkungan, Vol.1, No. 1, Januari $2000: 10-16$.

- Sutrasno Kartohardjono, Anggara, Subihi, dan Yuliusman.2007. Absorbsi $\mathrm{CO}_{2}$ Dari Campurannya Dengan $\mathrm{CH}_{4}$ Atau $\mathrm{N}_{2}$ Melalui Kontaktor Membran Serat Berongga Menggunakan Pelarut Air. Makara, Teknologi, Vol. 11, No. 2, November 2007: 97-102

- Total Fina ELF. 2002. Oil And Gas Processing Plant Design And Operation Training Course Gas Sweetening Processes. 